\title{
Benylin dependence, metabolic acidosis and hyperglycaemia
}

\author{
S. MacRury, R. Neilson and K. Goodwin ${ }^{1}$ \\ Medical Unit and 'Pharmacy, Glasgow Royal Infirmary, 84 Castle Street, Glasgow G4 OSF, UK.
}

\begin{abstract}
Summary: We describe a patient who had consumed large quantities of a proprietary cough mixture containing diphenhydramine, ammonium chloride and sodium citrate (Benylin expectorant) daily for several months and subsequently presented with confusion, marked metabolic acidosis and non-ketotic hyperglycaemia.
\end{abstract}

\section{Introduction}

Many drugs present problems with dependence and compulsive use. Although not strictly addictive, Benylin cough syrup can be considered in this group.' Benylin expectorant contains diphenydramine hydrochloride, ammonium chloride and sodium citrate. In therapeutic doses the antihistamine component may cause drowsiness and anticholinergic side effects while large doses may result in psychotic behaviour. With habitual use of large amounts of Benylin expectorant, effects of excess ammonium chloride may be encountered.

\section{Case report}

Our patient was a 69 year old man who had consumed various quantities of Benylin syrup intermittently for several years for insomnia. Following the death of his wife his consumption increased to two, $125 \mathrm{ml}$ bottles daily over a period of 10 months and, in addition, he took $60-80 \mathrm{mg}$ temazepam nightly. He spent most of his time in bed and rarely left the house.

On the morning of admission to hospital, he had been found lying on top of his bed by his daughter, unrousable and cold to the touch. His family described him as being generally unwell over the preceding fortnight and he had recently started on a tricyclic antidepressant although there was no evidence of deliberate self-poisoning.

On arrival at hospital he was unconscious and had a core temperature of $30^{\circ} \mathrm{C}$. There was bilateral ulceration of the lower limbs and pressure areas. Blood pressure was $90 / 60 \mathrm{mmHg}$ and pulse 90 per minute in sinus rhythm.

Initial biochemistry showed dehydration with metabolic acidosis (anion gap 20) and hyperglycaemia

Correspondence: S. MacRury, M.R.C.P.

Accepted: 5 January 1987
(Table I). Serum osmolality was $329 \mathrm{mmol} / \mathrm{l}$, serum lactate was $2.4 \mathrm{mmol} / \mathrm{l}$ and there were no ketone bodies. Serum amylase was $3866 \mathrm{U} / 1$ (normal range 70-300 U/1).

Rehydration was started with $0.9 \%$ saline and potassium chloride supplementation and in addition an intravenous insulin infusion was given at 4 units per hour. He improved considerably over the next 12 hours with his temperature rising to $36^{\circ} \mathrm{C}$ and by the second evening after admission the acidosis had resolved and he was fully orientated.

Unfortunately he developed septicaemia from a rapidly progressive coagulase positive Staphylococcus aureus infection in his left leg which necessitated a below knee amputation. Despite a good initial postoperative recovery, he collapsed and died one week later.

\section{Discussion}

Benylin expectorant contains $14 \mathrm{mg}$ diphenhydramine, $135 \mathrm{mg}$ ammonium chloride and $57 \mathrm{mg}$ sodium citrate per $5 \mathrm{ml}$. The equivalent amounts in $250 \mathrm{ml}$ (i.e. two $125 \mathrm{ml}$ bottles) would be $700 \mathrm{mg}, 6.75 \mathrm{~g}$ and $2.85 \mathrm{~g}$ respectively.

Diphenhydramine is a basic drug which is metabolized in the liver and excreted in the urine. Its toxic effects include anticholinergic effects and, when taken in large amounts, psychotic behaviour and convulsions. Ammonium chloride has a mild diuretic effect and acidifies the urine in doses of $1-2 \mathrm{~g} /$ day. Metabolic acidosis has previously been described with excessive doses of ammonium chloride in healthy subjects and in patients with congestive cardiac failure $^{2-4}$ given it as a diuretic. In one report transient hyperglycaemia was observed, ${ }^{3}$ and ammonium chloride acidosis has been shown to impair glucose utilization in dogs. ${ }^{5}$

(C) The Fellowship of Postgraduate Medicine, 1987 
Table I Biochemistry results

\begin{tabular}{|c|c|c|c|c|c|c|c|c|c|}
\hline Date & Time & $\begin{array}{c}\mathrm{Na} \\
(\mathrm{mmol} / \mathrm{l})\end{array}$ & $\begin{array}{c}K \\
(\mathrm{mmol} / \mathrm{l})\end{array}$ & $\begin{array}{c}\mathrm{Cl} \\
(\mathrm{mmol} / \mathrm{l})\end{array}$ & $\begin{array}{c}\mathrm{CO}_{2} \\
(\mathrm{mmol} / \mathrm{l})\end{array}$ & $\begin{array}{c}\text { Urea } \\
(\mathrm{mmol} / \mathrm{l})\end{array}$ & $\begin{array}{c}\text { Creatinine } \\
(\mu \mathrm{mol} / \mathrm{l})\end{array}$ & $\begin{array}{l}\text { Glucose } \\
\text { (mmol/l) }\end{array}$ & $p H$ \\
\hline \multirow[t]{2}{*}{8.3 .86} & On admission & 129 & 3.6 & 93 & 9 & 20.4 & - & 43.6 & 7.01 \\
\hline & 6 hours later & 133 & 3.2 & 99 & 10 & 21 & - & 32 & 7.15 \\
\hline 9.3.86. & $0900 \mathrm{~h}$ & 142 & 4.8 & 110 & 13 & 22 & 260 & 24 & 7.34 \\
\hline 10.3.86. & $0900 \mathrm{~h}$ & 149 & 5.1 & 122 & 17 & 19.5 & 170 & 2.8 & - \\
\hline 11.3.86. & $0900 \mathrm{~h}$ & 146 & 4.9 & 114 & 22 & 16.7 & 160 & 6.8 & - \\
\hline
\end{tabular}

It would seem likely that our patient was in a state of chronic metabolic acidosis which was further exacerbated by his subsequent admission with hypothermia. This latter may have been precipitated by septicaemia or by the addition of a tri-cyclic antidepressant to his already large intake of drugs. His marked hyperglycaemia on admission was probably contributed to by excessive ammonium chloride, long-standing metabolic acidosis, sepsis and hypothermia. It resolved quickly and he remained normoglycaemic thereafter.

Benylin expectorant is a ubiquitous preparation which may be taken in large doses on a regular basis, often for insomnia, perhaps with a degree of depen-

\section{References}

1. Anonymous. Is there any evidence that benylin syrup is addictive? Br Med J 1979, 1: 459.

2. Wood, F.J.Y. Ammonium chloride acidosis. Clin Sci 1955, 14: 81-89.

3. Relman, A.S., Shelburne, P.F. \& Talman, A. Profound acidosis resulting from excessive ammonium chloride in previously healthy subjects. $N$ Engl J Med 1961, 264: 848852. dency, by people believing it to be innocuous. They may not mention taking this medication when present- $\stackrel{\omega}{\sigma}$ ing to a doctor. It is possible that it is responsible for some cases of major metabolic acidosis and hyper- -3 glycaemia, presenting a picture strongly suggestive of diabetic hyperosmolar coma. A detailed history of consumption of any cough mixtures, or over-the- $A$ counter medicines should be taken in all patients to avoid inappropriate therapy being instituted.

\section{Acknowledgement}

We thank Professor D.H. Lawson for his assistance with this case.

4. Sleisenger, M.H. \& Freedberg, A.S. Ammonium chloride acidosis - a report of six cases. Circulation 1951, 111: 837845.

5. Makler, B., Lichtenstein, H. \& Guest, G.M. Effects of ammonium chloride acidosis on glucose tolerance in dogs, Am J Physiol 1952, 168: 126-130. 